\title{
TINDAK KEKERASAAN TERHADAP ISTERI DALAM UU NO 23 TAHUN 2004 DAN HUKUM ISLAM
}

\author{
Tasriani \\ Fakultas Ekonomi dan Ilmu Sosial, UIN Suska Riau \\ E-mail: tasri_musda@yahoo.co.id, HP.081275-51503
}

\begin{abstract}
This article discussed the violence in domestic area especially the violence against the househould in the perspective of the act No 23 of 2004 and the Islamic law. Both the act No 23 of 2004 and the Islamic law have the same spirit that is respect to woman prestige, especially househoul and fight against discrimination. In the act No 23 of 2004 is stated regarding the rule of its crime, while in the Islamic law does not stated it. Islamic law just returned it to the concept of marriage in Islam which known as the concept of sakinah, mawaddah, warahmah. It is clear that the violence againts the househould is not enabled in the perspective of the act No 23 of 2004 and the Islamic law.
\end{abstract}

Kata Kunci: tindak kekerasan, isteri, UU No 23 Th 2004, hukum Islam

\section{PENDAHULUAN}

Di beberapa negara, masalah kekerasan terhadap perempuan khususnya kekerasan dalam rumah tangga (KDRT) sudah direspon dengan baik. Kejahatan ini dapat dibawa ke pengadilan dan mereka yang menjadi korban difasilitasi dalam proses hukum khusus dalam menuntut hak-hak dan kompensasi yang dibutuhkannya. Tercatat sejumlah negara telah lebih dahulu 
memberlakukan Undang-Undang mengenai KDRT ini di antaranya Malaysia memberlakukan Akta Keganasan Rumah Tangga (1994), Selandia Baru, Australia, Jepang, Karibia, Meksiko dan beberapa negara bagian di Amerika Serikat.

Bagaimana di Indonesia? Indonesia juga sudah melakukan upaya kongkrit untuk melindungi korban kekerasan dalam rumah tangga melalui Undang-Undang No 23 tahun 2004 tentang Penghapusan Tindak Kekerasan dalam Rumah Tangga (PKDRT). Kenyataannya, enam tahun setelah diterbitkanya undang-Undang ini, jumlah kasus kekerasan terhadap perempuan masih cukup tinggi. LBH Asosiasi Perempuan Indonesia untuk keadilan (APIK) Semarang mencatat sepanjang Januari - Juni 2007 terjadi 44 kasus kekerasan dalam rumah tangga, akan tetapi dari 44 kasus itu hanya sembilan korban yang menempuh upaya hukum. Lima korban lapor ke polisi, tiga korban mengajukan gugatan cerai, dan seorang melapor kepada instansi di mana pelaku bekerja. ${ }^{1}$ Data Women's Crisis Centre (WCC) menunjukkan bahwa $74 \%$ kasus kekerasan terhadap perempuan pada tahun 2006 adalah kasus KDRT. Begitu juga pada tahun 2007, 87\% dari perempuan korban kekerasan yang mengakses layanannya mengalami KDRT di mana isteri banyak menjadi korban dan pelaku kekerasan terbanyak adalah suami dan mantan suaminya $(82,75 \%)^{2}$

Kekerasan dalam Rumah Tangga khususnya kekerasan terhadap isteri bukanlah persoalan domestik (privat) yang tidak boleh diketahui orang lain. KDRT merupakan pelanggaran hak asasi manusia dan kejahatan terhadap martabat kemanusiaan serta bentuk diskriminasi yang harus dihapuskan. Di berlakukannya UU No 23 Tahun 2004 merupakan jaminan yang diberikan negara untuk mencegah terjadinya kekerasan dalam rumah tangga, menindak pelaku KDRT, dan melindungi korban KDRT. Undang-undang ini juga tidak bertujuan untuk mendorong perceraian, sebagaimana sering dituduhkan orang. Justru Undang-undang ini bertujuan untuk memelihara keutuhan rumah tangga yang harmonis dan sejahtera dengan mencegah segala bentuk kekerasan sekaligus melindungi korban dan menindak pelaku kekerasan dalam rumah tangga. Di sisi lain, Al Quran sebagai sumber hukum Islam memang tidak mencakup seluruh persoalan kekerasan terhadap perempuan, namun banyaknya ayat yang berbicara mengenai kekerasan terhadap perempuan sudah cukup menjadi bukti bahwa Islam sangat memberi perhatian terhadap kekerasan dalam rumah tangga. Artikel ini mendiskusikan bagaimana sesungguhnya kekerasan terhadap perempuan khususnya terhadap isteri dalam UU No 23 tahun 2004 dan dalam hukum Islam.

\section{PEMBAHASAN}

Definisi Tindak Kekerasan terhadap Perempuan 
Dalam Deklarasi PBB (1993) pasal 1 dinyatakan bahwa : kekerasan terhadap perempuan adalah "setiap tindakan berdasarkan perbedaan jenis kelamin (gender-based violence) yang berakibat atau mungkin berakibat kesengsaraan atau penderitaan perempuan secara fisik, seksual atau psikologis, termasuk ancaman tindakan tertentu, pemaksaan atau perampasan kemerdekaan secara sewenang-wenang, baik yang terjadi di depan umum atau dalam kehidupan pribadi". Selanjutnya pasal 2 dari Deklarasi menyatakan : "kekerasan terhadap perempuan harus dipahami mencakup, tetapi tidak hanya terbatas pada : tindak kekerasan secara fisik, seksual dan psikologis yang terjadi di dalam keluarga dan di masyarakat, termasuk pemukulan, penyalahgunaan seksual atas perempuan dan anak-anak, kekerasan yang berhubungan dengan mas kawin, perkosaan dalam perkawinan (marital rapes), pengrusakan alat kelamin perempuan dan praktek-praktek kekejaman tradisional lain terhadap perempuan, kekerasan di luar hubungan suami isteri dan kekerasan yang berhubungan dengan eksploitasi perempuan, perkosaan, penyalahgunaan seksual, pelecehan dan ancaman seksual di tempat kerja, dalam lembaga-lembaga pendidikan dan sebagainya, perdagangan perempuan dan pelacuran paksa, serta termasuk kekerasan yang dilakukan dan dibenarkan oleh negara di manapun terjadinya". ${ }^{3}$

Dengan demikian, ruang lingkup kekerasan terhadap perempuan terjadi dalam rumah tangga (keluarga), di masyarakat luas (tempat publik) serta yang di wilayah negara. Landasan hukum perumusan ini adalah konvensi Penghapusan Segala Bentuk Diskriminasi terhadap Perempuan (1979) dan dikuatkan oleh Rekomendasi Umum CEDAW (Convention on The Elimination of All Forms Of Discrimination Against Women) No. 19/1992 tentang kekerasan berbasis gender dan merupakan suatu bentuk diskriminasi terhadap perempuan. ${ }^{4}$

Menurut Herkutanto, kekerasan terhadap perempuan adalah tindakan atau sikap yang dilakukan dengan tujuan tertentu sehingga dapat merugikan perempuan baik secara fisik maupun secara psikis. Hal penting lainnya ialah bahwa suatu kejadian yang bersifat kebetulan (eccidental) tidak dikategorikan sebagai kekerasan walaupun menimbulkan kerugian pada perempuan. ${ }^{5}$ Pengertian di atas tidak menunjukkan bahwa pelaku kekerasan terhadap perempuan hanya kaum pria saja, kaum perempuanpun dapat dikategorikan sebagai pelaku kekerasan.

\section{Tindak Kekerasan dalam Rumah Tangga Menurut UU No. 23 Tahun 2004}

Membicarakan tindak kekerasan terhadap isteri tidak dapat dipisahkan dari membicarakan tindak kekerasan dalam rumah tangga, karena isteri berada dalam lingkup wilayah tersebut. Deklarasi Penghapusan Segala Bentuk Kekerasan terhadap Perempuan membagi ruang lingkup terjadinya Kekerasan 
terhadap Perempuan atas 3 lingkup, yaitu di keluarga atau domestic, di masyarakat atau public domain serta dilakukan oleh negara atau state.

Menurut UU RI No. 23 tahun 2004 tentang Penghapusan Kekerasan dalam Rumah Tangga (PKDRT), Kekerasan dalam Rumah Tangga adalah setiap perbuatan terhadap seseorang terutama perempuan yang berakibat timbulnya kesengsaraan atau penderitaan secara fisik, seksual, psikologis, atau penelantaran rumah tangga termasuk juga hal-hal yang mengakibatkan ketakutan, hilangnya rasa percaya diri, hilangnya kemampuan untuk bertindak, rasa tidak percaya, atau penderitaan psikis berat pada seseorang. ${ }^{6}$

\section{Bentuk-bentuk Kekerasan terhadap Perempuan dalam Rumah Tangga Menurut UU No 23 tahun 2004}

Kekerasan Dalam Rumah Tangga (KDRT) atau Domestic violence juga dikenal sebagai tindakan pemukulan terhadap isteri, penyiksaan terhadap isteri, penyiksaan terhadap pasangan, kekerasan dalam perkawinan atau kekerasan dalam keluarga. Menurut Laporan Bank Dunia tahun 1994, bentuk kekerasan terhadap perempuan yang terbanyak kejadiannya adalah penyiksaan terhadap isteri atau tepatnya penyiksaan terhadap perempuan dalam relasi hubungan intim yang mengarah pada sistematika kekuasaan dan kontrol, di mana penyiksa berupaya untuk menerapkannya terhadap isterinya atau pasangan intimnya melalui penyiksaan secara fisik, emosi, sosial, seksual dan ekonomi.

Untuk lebih jelasnya mengenai bentuk-bentuk kekerasan terhadap perempuan, penulis mencantumkan pasal demi pasal sebagaimana yang tertuang dalam pasal 5 - 9 Undang-Undang PKDRT.

Pasal 5 "Setiap orang dilarang melakukan kekerasan dalam rumah tangga terhadap orang dalam lingkup rumah tangganya, dengan cara: (a) Kekerasan fisik (b) Kekerasan psikis (c) Kekerasan seksual, atau (d) Penelantaran rumah tangga".

Pasal 6 "Kekerasan fisik sebagaimana dimaksud dalam pasal 5 huruf (a) adalah perbuatan yang mengakibatkan rasa sakit, jatuh sakit, atau luka berat".

Pasal 7 "Kekerasan psikis sebagaimana dimaksud dalam pasal 5 huruf b adalah perbuatan yang mengakibatkan ketakutan, hilangnya rasa percaya diri, hilangnya kemampuan untuk bertindak, rasa tidak berdaya, dan/atau penderitaan psikis berat pada seseorang.

Pasal 8 "Kekerasan seksual sebagaimana dimaksud dalam pasal 5 huruf c meliputi: (a) Pemaksaan hubungan seksual yang dilakukan terhadap orang yang menetap dalam lingkup rumah tangga tersebut (b) Pemaksaan hubungan seksual terhadap salah seorang dalam lingkup rumah tangganya dengan orang lain untuk tujuan komersial dan/atau tujuan tertentu"

Pasal 9 (1) Setiap orang dilarang menelantarkan orang dalam lingkup rumah tangganya, padahal menurut hukum yang berlaku baginya atau karena 
persetujuan atau perjanjian ia wajib memberikan kehidupan, perawatan, atau pemeliharaan kepada orang tersebut. (2) Penelantaran sebagaimana dimaksud ayat (1) juga berlaku bagi setiap orang yang mengakibatkan ketergantungan ekonomi dengan cara membatasi dan atau melarang untuk bekerja yang layak di dalam atau di luar rumah sehingga korban berada di bawah kendali orang tersebut

Menurut Herkutanto bentuk-bentuk kekerasan dapat berupa (1) kekerasan psikis, bentuk tindakan ini sulit untuk dibatasi pengertiannya karena sensifitas emosi seseorang sangat bervariasi. Dalam suatu rumah tangga hal ini dapat berupa tidak diberikannya suasana kasih sayang pada isteri agar tidak terpenuhi kebutuhan emosionalnya. Identifikasi yang timbul pada kekerasan psikis lebih sulit diukur dari pada kekerasan fisik. (2) kekerasan fisik, bila didapati perlakuan bukan karena kecelakaan pada perempuan. Perlakuan itu dapat diakibatkan oleh suatu episode kekerasan yang tunggal atau berulang, dari yang ringan hingga yang fatal. ${ }^{7}$

\section{Ketentuan Pidana dalam Pasal 44 - 53 Undang-Undang No. 23 Th. 2004}

Pasal 44 (1) Setiap orang yang melakukan perbuatan kekerasan fisik dalam lingkup rumah tangga sebagaimana dimaksud dalam pasal 5 huruf a dipidana dengan pidana penjara paling lama 5 (lima) tahun atau denda paling banyak Rp. 15. 000.000,00 (Lima belas juta rupiah). (2) Dalam hal perbuatan sebagaimana dimaksud pada ayat (1) mengakibatkan korban mendapat jatuh sakit atau luka berat, dipidana dengan pidana penjara paling lama 10 (sepuluh) tahun atau denda paling banyak Rp. 30.000.000,00 (tiga puluh juta rupiah) (3) Dalam hal perbuatan sebagaimana dimaksud pada ayat (2) mengakibatkan matinya korban, dipidana dengan pidana penjara paling lama 15 (lima belas) tahun atau denda paling banyak Rp. 45.000.000,00 (empat puluh juta rupiah) (4) Dalam hal sebagaimana dimaksud pada ayat (1) dilakukan oleh suami terhadap isteri atau sebaliknya yang tidak menimbulkan penyakit atau halangan untuk menjalankan pekerjaan jabatan atau mata pencaharian atau kegiatan seharihari, dipidana dengan pidana penjara paling lama 4 (empat) bulan atau denda paling banyak Rp. 5.000.000,00 (lima juta rupiah)."

Pasal 45 (1) Setiap orang yang melakukan perbuatan kekerasan psikis dalam lingkup rumah tangga sebagaimana dimaksud pada pasal 5 huruf b dipidana dengan penjara paling lama 3 (tiga) tahun atau denda paling banyak Rp. 9.000.000,00 (sembilan juta rupiah) (2) Dalam hal perbuatan sebagimana dimaksud pada ayat (1) dilakukan oleh suami terhadap isteri atau sebaliknya yang tidak menimbulkan penyakit atau halangan untuk menjalankan pekerjaan jabatan atau mata pencaharian atau kegiatan sehari-hari dipidana penjara paling lama 4 (empat) bulan atau denda paling banyak Rp. 3.000.000,00 (tiga juta rupiah)." 
Pasal 46 "Setiap orang yang melakukan perbuatan kekerasan seksual sebagaimana dimaksud pada pasal 8 huruf a dipidana penjara paling lama 12 (dua belas) tahun atau denda paling banyak Rp. 36.000.000,00 (tiga puluh enam juta rupiah)."

Pasal 47 "Setiap orang yang memaksa orang yang menetap dalam rumah tangganya melakukan hubungan seksual sebagaimana dimaksud dalam Pasal 8 huruf $b$ dipidana penjara paling singkat 4 (empat) tahun dan pidana penjara paling lama 15 (lima belas) tahun atau denda paling sedikit Rp. 12.000.000,00 (dua belas juta rupiah) atau denda paling banyak Rp. 300.000.000,00 (tiga ratus juta rupiah)."

Pasal 48 "Dalam hal perbuatan sebagaimana dimaksdud dalam Pasal 46 dan Pasal 47 mengakibatkan korban mendapat luka yang tidak memberi harapan akan sembuh sama sekali, mengalami gangguan daya pikir atau kejiwaan sekurang-kurangnya selama 4 (empat) minggu terus menerus atau 1 (satu) tahun tidak berturut-turut, gugur atau matinya janin dalam kandungan, atau mengakibatkan tidak berfungsinya alat reproduksi, dipidana dengan pidana penjara paling lama 20 (dua puluh) tahun atau denda paling sedikit Rp 25.000.000,00 (dua puluh lima juta rupiah)."

Pasal 49, dipidana dengan pidana penjara paling lama 3 (tiga) tahun atau denda paling banyak Rp 15.000.000,00 (lima belas juta rupiah), setiap orang yang: a. Menelantarkan orang lain dalam lingkup rumah tangganya sebagaimana dimaksud dalam pasal 9 ayat (1). b. Menelantarkan orang lain sebagaimana dimaksud Pasal 9 ayat (2).

Pasal 50, selain dipidana sebagaimana dimaksud dalam bab ini, hakim dapat menjatuhkan pidana tambahan berupa: (a) pembatasan gerak pelaku baik yang bertujuan untuk menjatuhkan pelaku dari korban dalam jarak dan waktu tertentu, maupun pembatasan hak-hak tertentu dari pelaku. (b) Penetapan pelaku mengikuti program konseling di bawah pengawasan lembaga tertentu Pasal 51 "tindak pidana kekerasan fisik sebagaimana dimaksud dalam Pasal 44 ayat (4) merupakan delik aduan".

Pasal 52 "tindak pidana kekerasan psikis sebagaimana dimaksud dalam pasal 46 yang dilakukan oleh suami terhadap isteri atau sebaliknya merupakan delik aduan".

Pasal 53 "tindak pidana kekerasan seksual sebagaimana dimaksud dalam Pasal 46 yang dilakukan oleh suami terhadap isteri atau sebaliknya merupakan delik aduan." 8

\section{Faktor Terjadinya Kekerasan dalam Rumah Tangga Khususnya terhadap Isteri}

Ada beberapa faktor-faktor yang menyebabkan terjadinya tindak kekerasan dalam rumah tangga, yaitu faktor eksternal dan internal. Faktor eksternal berkaitan erat dengan kekuasaan suami dan diskriminasi di kalangan 
masyarakat. Di antaranya: (a) Budaya patriarkhi yang menempatkan pada posisi laki-laki dianggap lebih unggul dari pada perempuan dan berlaku tanpa perubahan, seolah-olah itulah kodrati. (b) Interpretasi agama, yang tidak sesuai dengan universal agama, misalnya seperti nusyuz, yakni suami boleh memukul isteri dengan alasan mendidik atau isteri tidak mau melayani kebutuhan seksual suami, maka suami berhak memukul dan isteri dilaknat malaikat. (c) Kekerasan berlangsung justru tumpang tindih dengan legitimasi dan menjadi bagian dari budaya, keluarga, negara dan praktek di masyarakat sehingga menjadi bagian kehidupan.

Faktor-faktor eksternal lain yang menyebabkan terjadinya kekerasan dalam rumah tangga antara lain: (a) Labelisasi perempuan dengan kondisi fisik yang lemah cenderung menjadi anggapan objek pelaku kekerasan sehingga pengkondisian lemah ini dianggap sebagai pihak yang kalah dan dikalahkan. Hal ini seringkali dimanfaatkan laki-laki untuk mendiskriminasikan perempuan sehingga perempuan tidak dilibatkan dalam berbagai peran strategis. Akibat dari labeling ini, seringkali laki-laki memanfaatkan kekuatannya untuk melakukan kekerasan terhadap perempuan baik secara fisik, psikis, maupun seksual. (b) Kekuasaan yang berlindung di bawah kekuatan jabatan juga menjadi sarana untuk melakukan kekerasan. Jika hakekat kekuasaan sesungguhnya merupakan kewajiban untuk mengatur, bertanggung jawab dan melindungi pihak yang lemah, namun seringkali kebalikannya bahwa dengan sarana kekuasaan yang legitimate, penguasa seringkali melakukan kekerasan terhadap warga atau bawahannya. Dalam kontek ini misalnya negara terhadap rakyat dalam berbagai bentuk kebijakan yang tidak sensitif pada kebutuhan rakyat kecil. (c) Sistem ekonomi kapitalis juga menjadi sebab terjadinya kekerasan terhadap perempuan. Dalam sistem ekonomi kapitalis dengan prinsip ekonomi cara mengeluarkan modal sedikit untuk mencapai keuntungan sebanyak-banyaknya, maka memanfaatkan perempuan sebagai alat dan tujuan ekonomi akan menciptakan pola eksploitasi terhadap perempuan dan berbagai perangkat tubuhnya. Oleh karena itu perempuan menjadi komoditas yang dapat diberi gaji rendah atau murah. ${ }^{9}$

Faktor internal timbulnya kekerasan terhadap isteri adalah kondisi psikis dan kepribadian suami sebagai pelaku tindak kekerasan yaitu: (a) sakit mental, (b) pecandu alkohol, (c) penerimaan masyarakat terhadap kekerasan, (d) kurangnya komunikasi, (e) penyelewengan seks, (f) citra diri yang rendah, (g), frustasi, (h) perubahan situasi dan kondisi, (i) kekerasan sebagai sumber daya untuk menyelesaikan masalah, (j)pola kebiasaan keturunan dari keluarga atau orang tua. ${ }^{10}$

Hampir semua bentuk kekerasan dalam keluarga dilakukan oleh lakilaki misalnya pemukulan terhadap isteri, pemerkosaan dalam keluarga dan lain sebagainya. Semua itu jarang menjadi bahan pemberitaan masyarakat karena dianggap tidak ada masalah, sesuatu yang tabu atau tidak pantas dibicarakan. 
Dari berbagai bentuk kekerasan yang menjadi korban pada umumnya adalah perempuan lebih khususnya lagi adalah isteri cenderung diam karena merasa sia-sia. Para korban biasanya malu bahkan tidak berani menceritakan keadaannya kepada orang lain.

\section{Dampak Kekerasan dalam Rumah Tangga}

Tindak kekerasan yang dilakukan terhadap perempuan, seperti pemerkosaan, penganiayaan, pelecehan seksual merupakan peristiwa kejahatan yang sangat merugikan karena menimbulkan dampak negatif bagi kehidupannya. Tindakan kekerasan ini selalu disertai dengan kekerasan fisik dan psikis sehingga mengganggu kesehatan reproduksi dan gangguan kesehatan mental bahkan potensial terjadi kematian atau korban bunuh diri. Data dari Women's Crises Centre (WCC) menunjukkan 9 dari 10 perempuan korban kekerasan yang didampingi oleh WCC mengalami gangguan kesehatan jiwa, 12 orang pernah mencoba bunuh diri; dan 13,12\% dari mereka menderita gangguan kesehatan reproduksinya. ${ }^{11}$

Gangguan kesehatan reproduksi yang dialami perempuan yang mengalami perkosaan di antaranya infeksi saluran reproduksi, infeksi menular seksual (IMS), termasuk infeksi HIV dan AIDS, kehamilan yang tidak dikehendaki, abortus spontan, pemaksaan abortus, berat bayi lahir rendah (BBLR), kecacatan pada bayi dan kerusakan organ genital atau reproduksi. Memaksakan dilanjutkannya kehamilan yang tidak diinginkan oleh korban perkosaan akan meningkatkan resiko kehamilan perempuan. Tekanan psikis dan trauma yang dialami oleh perempuan hamil tersebut akan membayangi kehidupannya.

Elly Nurhayati dan Wahid Hasyim membagi dampak kekerasan yang dialami oleh perempuan ke dalam dampak jangka panjang dan jangka pendek. Dampak jangka panjang biasanya akan menimbulkan trauma yang sering disebut dengan istilah dialektika trauma dalam bentuk (1) hyper arousal yaitu emosional yang labil, kadang-kadang naik dalam bentuk marah, mengamuk, menyerang dan menurun dalam bentuk depresi, sedih, menangis dan sebagainya. Emosi labil ini bisa selang seling atau salah satu tapi intens. (2) intrusion yaitu gejala kekacauan kognitif yang ditandai dengan pikiran yang dipenuhi dengan kilas balik (flash back) peristiwa-kejadian atau mimpi-mimpi buruk (nightmare). (3) nubing yaitu mati rasa atau keadaan emosi yang dalam dan dingin seolah-olah tidak memiliki kemauan dan harapan, serta bengong, dan sebagainya. Jika hal ini terjadi terus menerus, korban menjadi indifferent (acuh tak acuh) dan detached (terpisah dari interaksi sosial). ${ }^{12}$

Dampak kekerasan yang dialami oleh isteri dapat menimbulkan akibat secara kejiwaan seperti kecemasan, murung, stres, minder, kehilangan kepercayaan kepada suami, menyalahkan diri sendiri dan sebagainya. Akibat secara fisik seperti memar, patah tulang, cacat fisik, ganggungan menstruasi, 
kerusakan rahim, keguguran, terjangkit penyakit menular, penyakit-penyakit psikomatis bahkan kematian. Dampak psikologis lainnya akibat kekerasan yang berulang dan dilakukan oleh orang yang memiliki hubungan intim dengan korban adalah jatuhnya harga diri dan konsep diri korban (ia akan melihat diri negatif, banyak menyalahkan diri) maupun depresi dan bentukbentuk gangguan lain sebagai akibat dan bertumpuknya tekanan, kekecewaan dan kemarahan yang tidak dapat diungkapkan. ${ }^{13}$

Penderitaan akibat penganiayaan dalam rumah tangga tidak terbatas pada isteri saja, tetapi menimpa juga pada anak-anak. Anak-anak bisa mengalami penganiayaan secara langsung atau merasakan penderitaan akibat menyaksikan penganiayaan yang dialami ibunya, paling tidak setengah dari anak-anak yang hidup di dalam rumah tangga yang di dalamnya terjadi kekerasan juga mengalami perlakuan kejam. Sebagian besar diperlakukan kejam secara fisik, sebagian lagi secara emosional maupun seksual. Kehadiran anak di rumah tidak membuat laki-laki atau suami tidak menganiaya isterinya. Bahkan banyak kasus, laki-laki penganiaya memaksa anaknya menyaksikan pemukulan ibunya. Sebagian menggunakan perbuatan itu sebagai cara tambahan untuk menyiksa dan menghina pasangannya.

Menyaksikan kekerasan merupakan pengalaman yang sangat traumatis bagi anak-anak, mereka seringkali diam terpaku, ketakutan, dan tidak mampu berbuat sesuatu ketika sang ayah menyiksa ibunya, sebagian berusaha menghentikan tindakan sang ayah atau meminta bantuan orang lain. Menurut data yang terkumpul dari seluruh dunia anak-anak yang sudah besar akhirnya membunuh ayahnya setelah bertahun-tahun tidak bisa membantu ibunya yang diperlakukan kejam. Di antara ciri-ciri anak yang menyaksikan atau mengalami KDRT adalah: (a) sering gugup, (b) suka menyendiri, (c) cemas, (d) sering ngompol, (e) gelisah, (f) gagap, (g) seringg menderita gangguan perut, (h) sakit kepala dan asma, (i) kejam pada binatang, (j) ketika bermain meniru bahasa dan prilaku kejam, (k) suka memukul teman. ${ }^{14}$ Kekerasan dalam Rumah Tangga merupakan pelajaran pada anak bahwa kekejaman dalam bentuk penganiayaan adalah bagian yang wajar dari sebuah kehidupan. Anak akan belajar bahwa cara menghadapi tekanan adalah dengan melakukan kekerasan. Menggunakan kekerasan untuk menyelesaikan persoalan bagi anak sesuatu yang biasa dan baik-baik saja. KDRT memberikan pelajaran pada anak laki-laki untuk tidak menghormati kaum perempuan.

\section{Kekerasan dalam Rumah Tangga Menurut Hukum Islam}

Kekerasan dalam rumah tangga menurut hukum Islam sulit untuk dideteksi karena umumya terjadi di wilayah domestik yang mencakup hubungan perkawinan seperti poligami, kekerasan seksual, wali mujbir, belanja keluarga (ekonomi), talak, dan lain sebagainya. Al Quran sebagai sumber hukum Islam memang tidak mencakup seluruh persoalan kekerasan terhadap perempuan, namun banyaknya ayat yang berbicara mengenai kekerasan 
terhadap perempuan sudah cukup menjadi bukti bahwa Islam sangat memberi perhatian terhadap kekerasan dalam rumah tangga.

Kekerasan yang terjadi dalam rumah tangga dalam perspektif hukum Islam dapat wuduj dalam bentuk, pertama kekerasan fisik. Al-Qur'an dan hadits diyakini oleh semua umat Islam sebagai sumber acuan utama dalam semua tindakan. Kedua sumber tersebut dipelajari dan dikaji di lembaga pendidikan dan lapisan masyarakat, sehingga lumrah jika terjadi banyak penafsiran. Al-Qur'an memberi perhatian bagi isteri yang nusyuz dalam surat An-Nisa' [4] ayat 34. Kemudian ayat ini yang dijadikan dasar memberi pelajaran bagi isteri.

\begin{tabular}{|c|c|}
\hline ÆèdqÝàİèsù & Æèdy qà̀èS \\
\hline
\end{tabular}

Artinya:...wanita-wanita yang kamu khawatirkan nusyuznya, maka nasehatilah mereka dan pisahkanlah mereka di tempat tidur mereka, dan pukullah mereka. Kemudian jika mereka mentaatimu, maka janganlah kamu mencari-cari jalan untuk menyusahkannya....

Dalam tafsir al Azhar dijelaskan tindakan-tindakan yang patut dilakukan suami terhadap isteri yang nusyuz yaitu dengan cara, pertama, "maka ajarilah mereka, beri mereka petunjuk dan pengajaran, ajarilah mereka dengan baik, sadarkan mereka akan kesalahannya. Suami hendaklah menunjukkan pimpinan yang tegas dan bijaksana. Kedua yaitu dengan cara "pisahkanlah mereka dari tempat tidur" kerapkali isteri menjadi hilang kesombongannya karena pengajaran demikian. Tetapi ada pula perempuan yang harus dihadapi dengan cara yang lebih kasar, maka pakailah cara yang ketiga "dan pukullah mereka" tentu saja cara yang ketiga ini hanya dilakukan kepada perempuan yang sudah memang patut dipukul. ${ }^{15}$

Dari pemahaman surat An-Nisa' inilah banyak suami yang melakukan kekerasan terhadap isteri dalam segala bentuknya. Sebagian Ulama' menafsirkan pemukulan ini, Pertama, pemukulan tidak boleh diarahkan ke wajah. Kedua, pemukulan tidak boleh sampai melukai, dianjurkan dengan benda yang paling ringan, seperti sapu tangan. Ketiga pemukulan dilakukan dalam rangka mendidik. Keempat, pemukulan dilakukan dalam rangka sepanjang memberikan efek manfaat bagi keutuhan dan keharmonisan kembali relasi suami isteri. ${ }^{16}$

Nabi Muhammad SAW melarang seseorang melakukan kekejaman dan penyiksaan. Beliau bersabda, "tidak seorangpun boleh dijatuhi hukuman dengan api" dan juga memperingatkan agar tidak memukul siapapun pada wajahnya. Dalam hukum pidana, beberapa hukuman mungkin terlihat berat atau bahkan keras. Hukuman berat diancam bagi beberapa kejahatan seperti perzinaan. Islam memandang kejahatan tersebut adalah perbuatan yang keji 
dan konsekuensinya sangat menyakitkan. Contoh lainnya adalah pencurian yang dikategorikan dalam hukuman hudud, hukuman bagi kejahatan ini adalah potong tangan. ${ }^{17}$

Kedua, kekerasan psikis. Selain kekerasan fisik Islam juga memperhatikan kekerasan psikis, sebagaimana kisah Khaulah binti Tsa'labah mengadu kepada Rasulullah karena selalu dicaci maki oleh suaminya Aus bin Samit, Khaulah seorang muslimah yang taat beribadah dan taat pada suami, sehingga walaupun dicaci ia tetap bersabar. Pada suatu hari hilanglah kesabarannya karena dizhihar suaminya, lantaran marah hanya karena pulang tidak ada makanan. Malam harinya Khaulah menolak dicampuri suaminya. Peristiwa ini diajukan pada Rasulullah lalu turunlah surat al Mujadalah [58] ayat 1-6 tentang zhihar ayat ini mengandung makna agar para suami tidak mudah menzhihar isterinya. ${ }^{18}$

Ada sebuah hadits yang menjelaskan apabila seseorang telah mengilla' isterinya, mereka harus membayar kafarah ketika ia akan mengauli isterinya. Artinya: dari Aisyah ra. mengatakan "Rasulullah SAW bersumpah illa" terhadap isteri-isterinya dan mengharamkan mereka, kemudian menjadikan yang haram menjadi halal dan menyebar kafarah tebusan sumpahnya". ${ }^{19}$

Dalam hadist tersebut dijelaskan bahwa illa' itu merupakan sumpah untuk suami terhadap isterinya untuk tidak menggauli isterinya hingga waktu yang ditentukan. Para ulama sepakat ketika suami mengilla' isterinya selama 4 bulan berturut-turut maka tidak boleh menjima'nya. Suami ketika akan menjima' isterinya lagi ia harus membayar kifarat yaitu memerdekakan budak jika ada. Apabila tidak menemukan budak, maka puasa dua bulan berturutturut, apabila tidak mampu, maka memberi makan 60 orang miskin. ${ }^{20}$

Banyak ayat al-Qur'an yang menunjukkan bahwa antara perempuan dan laki-laki itu sama atau setara misalnya tentang kesempatan mendapatkan pahala, hubungan perempuan dengan laki-laki dan juga kerabatnya. Dalam hal kepemilihan, Islam memberi hak bagi perempuan untuk memilih jodoh. Semula hak itu ditentukan oleh wali, setelah Islam datang anak gadis yang akan dinikahkan, diajak bicara dan ikut menentukan pilihannya.

Ketiga, kekerasan seksual, yang dimaksud kekerasan ini adalah pemaksaan aktivitas seksual oleh satu pihak terhadap pihak lain yang disebut dengan marital rape. Dalam hal ini kekerasan yang dimaksud adalah kekerasan yang dilakukan suami terhadap isteri. Dengan demikian marital rape merupakan tindak kekerasan atau pemaksaan yang dilakukan oleh suami terhadap isteri untuk melakukan aktifitas seksual tanpa pertimbangan kondisi. 21

Berdasarkan pada beberapa pengertian marital rape di atas, dapat dirumuskan bentuk-bentuk marital rape sebagai berikut: (1) Hubungan seksual yang tidak dikehendaki isteri karena ketidak siapan isteri dalam bentuk fisik dan psikis. (2) Hubungan seksual yang tidak dikehendaki isteri misalnya 
dengan oral atau anal. (3) Hubungan seksual disertai ancaman kekerasan atau dengan kekerasan yang mengakibatkan isteri mengalami luka ringan ataupun berat. $^{22}$

Terkait dengan masalah seksualitas suami isteri, ada beberapa statemen al-Qur'an yang bisa dikemukakan di antaranya dalam surat al Baqarah [2] ayat 187 yaitu:

zÇÊẼĐÈ ...3 £’ßg(C9 Ó“\$t6Ï9 öNçFRr\&ur öNä3C9 Ó“\$t6Ï9 £’èd... Artinya:...Mereka (isteri-isterimu) adalah pakaian bagimu dan kamu adalah pakaian bagi mereka....

Ayat lain juga menyatakan bahwa suami harus menggauli isterinya dengan ma'ruf ini tentunya tidak diperbolehkan adanya kekerasan baik pemukulan, penganiayaan dan lain sebagainya. Al Syirazi mengatakan meskipun pada dasarnya isteri wajib melayani permintaan suami, akan tetapi jika memang tidak terangsang untuk melayaninya, ia boleh menawarnya atau menangguhkannya, dan bagi isteri yang sedang sakit atau tidak enak badan, maka tidak wajib baginya untuk melayani ajakan suami sampai sakitnya hilang. Jika suami tetap memaksa pada hakekatnya ia telah melanggar prinsip musyaroh bil ma'ruf dengan berbuat aniaya kepada pihak yang justru seharusnya ia lindungi. ${ }^{23}$

Ulama Madzhab (Imam Hanafi, Imam Maliki, dan Hambali) memandang 'azl (coitus interruptus) yakni menarik dzakar (penis) keluar dari farji (vagina) pada saat-saat mau keluar mani, tidak boleh dilakukan begitu saja oleh suami tanpa seizin isteri, dengan alasan dapat merusak kenikmatan isteri. Umar berkata: Rasulullah melarang seseorang melakukan 'azl tanpa seizin isterinya. (HR. Ibnu Majah). Hal ini sejalan dengan prinsip melindungi hak isteri untuk menikmati hubungan seksnya.

Dengan merujuk pada hadits di atas, jelas bagi kita bahwa dalam hubungan seks terutama ketika detik-detik kenikmatannya, isteri sama sekali bukan hanya objek tapi juga menjadi subjek. Dari sini jelaslah perspektif alQur'an melarang adanya pemaksaan hubungan seksual yang dilakukan suami terhadap isteri atau marital rape, karena bertentangan dengan prinsip-prinsip dasar Islam tentang seksualitas dalam perkawinan.

Keempat, kekerasan ekonomi yaitu apabila suami tidak memberikan nafkah, perawatan atau pemeliharaan sesuai dengan hukum yang berlaku atau perjanjian antara suami dan isteri tersebut. Selain itu juga yang termasuk dalam kategori penelantaran ekonomi adalah membatasi atau melarang untuk bekerja yang layak di dalam atau di luar rumah, sehingga korban di bawah kendali orang tersebut. Islam mengatur secara jelas melalui pengalaman-pengalaman masa kenabian Muhammad SAW. Melalui pengalaman-pengalaman di masa kenabian tersebut jelas ba terlihat bahwa Islam tidak mentoleransi penelantaran dan kekerasan dari segi ekonomi. Islam menetapkan kewajiban memberi nafkah kepada isteri, oleh karena itu seorang suami yang tidak memberi nafkah 
kepada isterinya telah berdosa kepada isterinya dan Tuhan. Isteri yang menuntut suami untuk membelikan sesuatu selain keperluan-keperluan pokok yang menjadi tanggung jawab suami ${ }^{24}$ harus benar-benar mempertimbangkan apakah menurut ajaran agama sesuatu yang dimintanya itu merupakan pemborosan ataukah benar-benar menjadi kebutuhan hidup.

Adapun keperluan isteri yang menjadi tanggung jawab suami adalah: (a) keperluan makan dan minum (b) keperluan pakaian (c) keperluan pengobatan dan pemeliharaan kesehatan, (d) seorang isteri juga hendaknya mempertimbangkan hal-hal yang akan diminta kepada suaminya, sehingga tidak membebani suami dengan tuntutan di luar kewajibanya. Dasar kewajiban suami menafkahi isteri tersebut terdapat dalam firman Allah surat Al Baqarah [2] ayat 233.

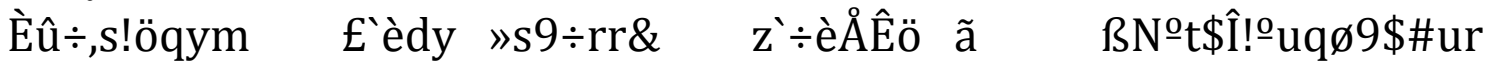

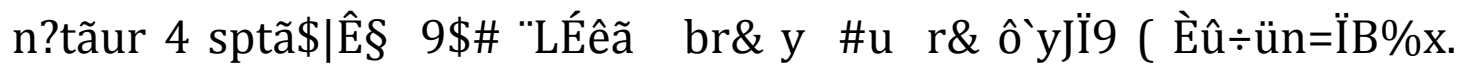

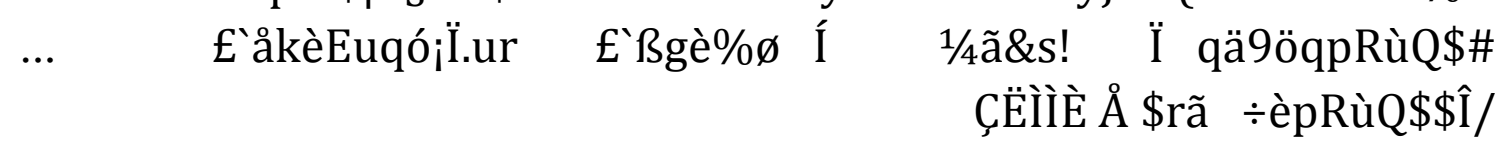

Artinya: Para ibu hendaklah menyusukan anak-anaknya selama dua tahun penuh, yaitu bagi yang ingin menyempurnakan penyusuan. dan kewajiban ayah memberi makan dan pakaian kepada para ibu dengan cara ma' ruf....

Dari beberapa paparan di atas jelas sekali bahwa Islam benar-benar melarang bertindak kekerasan terhadap isteri, termasuk juga penelantaran pemberian nafkah. Bahkan ketika terjadi ceraipun Islam tetap memberi perhatian terhadap perempuan, salah satunya adalah dengan adanya 'iddah, dan larangan mengambil kembali sesuatu yang telah diberikan kepadanya, hal ini dijelaskan dalam surat al-Baqarah [2] ayat 229:

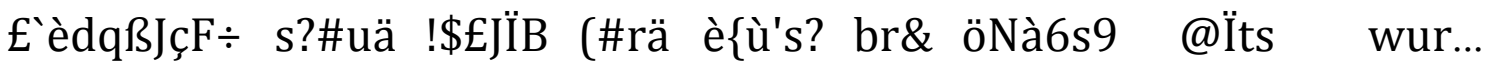

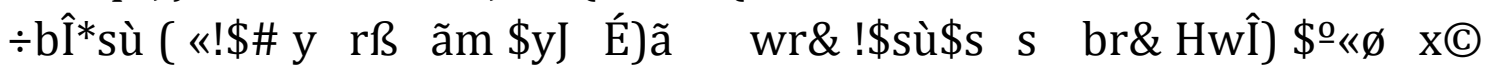
\$yJÍkö n=tã yy\$oYã_ xsù «!\$\# y rß ãn \$uK É)ã $\quad$ wr\& $\div$ LäêøÿÅz ÇËËÒÈ ... 3 3/4Ïmîl ôNy tGøù\$\# \$uK Ïù Artinya: ...Tidak halal bagi kamu mengambil kembali sesuatu dari yang telah kamu berikan kepada mereka, kecuali kalau keduanya khawatir tidak akan dapat menjalankan hukum-hukum Allah. Jika kamu khawatir bahwa keduanya (suami isteri) tidak dapat menjalankan hukum-hukum Allah, maka tidak ada dosa atas keduanya tentang bayaran yang diberikan oleh isteri untuk menebus dirinya....

\section{Faktor-Faktor Terjadinya Kekerasan terhadap Isteri}

Faktor-faktor yang menyebabkan terjadinya kekerasan terhadap isteri antara lain: (a) isteri melakukan nusyuz. Seperti yang telah dijelaskan di atas, suami boleh memukul istri yang nusyuz tetapi hanya pada bagian badan isteri, dan pemukulan ini boleh dilakukan jika memang membawa faedah, jika tidak maka tidak perlu melakukan pemukulan, (b) isteri tidak mengindahkan 
kehendak suami untuk berhias dan bersolek dan isteri menolak diajak ke tempat tidur, (c) isteri keluar dari rumah tanpa izin, (d) isteri menghina suami dengan kata-kata yang tidak enak didengar, (d) isteri berbincang-bincang dengan laki-laki lain bukan muhrimnya, (e) isteri tidak mandi haid ketika sudah memasuki waktu suci. Hal ini menyebabkan suami tidak bisa menggauli isterinya ${ }^{25}$.

Jika dipahami dengan seksama, surat an Nisak ayat 34 sesungguhnya tidak memperbolehkan kekerasan terhadap istri. Di dalam ayat tersebut jelas dinyatakan jika isteri nusyuz tindakan-tindakan yang patut dilakukan suami terhadap isteri harus bertahap, yaitu dengan cara beri istri petunjuk dan pengajaran, ajari mereka dengan baik, sadarkan mereka akan kesalahannya. Jika dengan cara ini isteri tetap saja membangkang, maka pisahkanlah mereka dari tempat tidur mereka, adapun mendiamkan isteri dengan tidak mengajak berbicara tidak boleh lebih dari 3 (tiga) hari. Ada pula perempuan yang harus dihadapi dengan cara yang lebih kasar, yaitu dengan cara pukulan, akan tetapi pemukulan ini tidak boleh membuat luka pada isteri. Dalam memukul hendaknya dijauhkan dari tempat-tempat yang mengkhawatirkan seperti muka serta dijauhkan dari pandangan anak-anaknya. Karena tujuan dari pemukulan ini yaitu untuk memberi pelajaran dan bukan untuk membinasakan.

Dalam pemukulan ini ada statemen yang perlu diperhatikan yaitu pertama, pemukulan tidak boleh diarahkan ke wajah, kedua, pemukulan tidak boleh sampai melukai, dianjurkan dengan benda yang paling ringan, seperti sapu tangan. Ketiga, pemukulan dilakukan dalam rangka mendidik. Keempat, pemukulan dilakukan dalam rangka sepanjang memberikan efek manfaat bagi keutuhan dan keharmonisan kembali relasi suami isteri. Apabila suami telah memberikan nafkah pada isterinya akan tetapi isteri tetap membangkang dan menyeleweng, suami berhak meminta kembali sisa nafkah yang telah diberikannya, artinya jika isteri tetap membangkang pada suaminya mereka tidak berhak mendapatkan nafkah, karena nafkah diterima sebagai imbalan terikatnya isteri dengan suami. Hal ini disepakati oleh Imam Syafi'i dan Hambali.

Dalam kafarat zhihar ketika suami mengilla' isterinya selama 4 bulan berturut-turut maka tidak boleh menjima'nya. ketika suami akan menjima' isterinya lagi ia harus membayar kifarat yaitu memerdekakan budak jika ada. Apabila tidak menemukan budak, maka puasa dua bulan berturut-turut, apabila tidak mampu, maka memberi makan 60 orang miskin

\section{Perbedaan dan Persamaan Pandangan tentang Tindak Kekerasan dalam Rumah Tangga antara UU No. 23 Tahun 2004 dan Hukum Islam}

Dalam hal pemberlakuan, Undang-Undang Penghapusan Kekerasan Dalam Rumah Tangga diberlakukan pada tanggal 22 September 2004 menjadi undang-undang. Hukum Islam telah diberlakukan beberapa abad yang lalu. 
Dalam hal tujuannya, Undang-undang Penghapusan Kekerasan Dalam Rumah Tangga mempunyai beberapa tujuan di antaranya: mencegah segala bentuk kekerasan dalam rumah tangga, melindungi korban kekerasan, menindak pelaku kekerasan dalam rumah tangga, memelihara keutuhan rumah tangga. Sedangkan dalam hukum Islam yaitu berbicara mengenai relasi suami isteri yang memberikan pengertian bahwa sebuah perkawinan harus dijalani dengan suasana hati yang damai, keseimbangan hak dan kewajiban antara suami isteri yang tidak lain tujuannya untuk menjadikan keluarga yang sakinah, mawaddah dan rahmah.

Ketentuan pidana dalam Undang-undang No. 23 Tahun 2004 sudah terperinci yaitu pasal 44 sampai dengan pasal 50, sedangkan dalam hukum Islam tindak pidana bersifat umum dan elastis sehingga bisa mencakup semua peristiwa seperti dalam had, qishos dan diyat dibatasi, sedangkan mengenai halhal yang sekiranya merupakan tindakan penganiayaan dalam firman Tuhan akan dihukum dengan dosa bagi orang yang melakukannya. Dalam UU PKDRT ditentukan satu atau dua hukuman dengan batas terendah dan tertinggi sehingga hakim terbatas dalam menentukan hukumannya. Dalam hukum Islam ditentukan secara jelas sehingga hakim tidak menciptakan sendiri dalam had, qishos dan diyat, sedang dalam $t a^{\prime} z i r$ memberi pilihan dan hakim bisa menghentikan pelaksanaan hukumannya.

Persamaan, dalam hal melakukan kekerasan pasal 5 huruf (a) "Setiap orang dilarang melakukan kekerasan dalam lingkup rumah tangganya dengan cara kekerasan fisik, kekerasan psikis, kekerasan seksual, atau penelantaran rumah tangga. Dalam hukum Islam menjelaskan pola relasi yang didasarkan pada mu'asyarah bil ma'ruf, maka jangan saling melakukan kekerasan baik isteri maupun suami. (b). Dalam hal asas yang digunakan Undang-undang No. 23 Tahun 2004 dengan asas penghormatan terhadap martabat manusia, serta anti kekerasan atau diskriminasi dan juga asas perlindungan terhadap korban. Sedangkan dalam al-Qur'an itu sendiri merupakan semangat pembebasan dalam menjalin keseimbangan antara nilai kemanusiaan.

\section{SIMPULAN}

Persoalan UU PKDRT dan Hukum Islam mempunyai semangat yang sama yang melandasi dua hukum tersebut yaitu penghormatan terhadap martabat manusia, kaitannya dengan hak-hak suami isteri dalam rumah tangga, serta anti kekerasan atau diskriminasi terhadap perempuan. Hanya saja dalam Undang-undang sudah jelas mengenai ketentuan pidananya, sedangkan dalam hukum Islam tidak didapatkan ketentuan pidana bagi mereka yang melakukan kekerasan terhadap isteri dalam rumah tangga, akan tetapi kembali pada konsep perkawinan yaitu sakinah, mawadah, warahmah. Dari sini jelaslah bahwa kekerasan terhadap isteri dalam rumah tangga menurut UU PKDRT dan hukum Islam tidak diperbolehkan. 
Sosialisasi undang-undang PKDRT terhadap masyarakat harus terus dilakukan karena sampai saat ini masih banyak masyarakat yang belum tahu UU PKDRT tersebut, sosialisasi pertama difokuskan kepada aparat penegak hukum, kemudian kepada masyarakat dengan memberi penyuluhanpenyuluhan hukum selanjutnya dilakukan sosialisasi kepada kalangan agamawan dan pemuka agama untuk mengubah kultur dan interpretasi agama.

\section{Endnotes:}

1 Suara Merdeka. 7 Agustus 2007.

2 http://www.djpp.depkumham.go.id/hukum-pidana/677-penegakan-hukum

3 Konferensi Dunia ke III tentang Perempuan di Beijing (Beijing Platform for Action). 1995. hlm 25-27. Dikeluarkannya Keppres No. 181 tahun 1996 tentang Komisi Nasional Anti Kekerasan Terhadap Perempuan.

4 Convention on the Elimination of All Form of Discrimination Against Women. hal 14. Ratifikasi Konvensi Wanita tahun 1979 melalui UU No. 7 tahun 1984. Dibentuk Kelompok Kerja Convention Watch pada Pasca Sarjana Kajian Wanita Universitas Indonesia

5 Herkutanto. 2000. Kekerasan Terhadap Perempuan dalam Sistem Hukum Pidana. dalam buku Penghapusan Diskriminasi Terhadap Wanita. Bandung: PT. Alumni. hlm. 267-268.

6 UU RI No. 23 tahun 2004 tentang Penghapusan Kekerasan dalam Rumah Tangga. 2006. Cet. II, Desember. Bandung: Pustaka Fokus Media. hlm. 5 ) 3

7 Op.cit, hlm. 16-19

$8 \quad$ Op.cit, hlm. 17-18

9 Mufidah et al. 2006. Haruskah Perempuan dan Anak Dikorbankan? Panduan Pemula Untuk Pendampingan Korban Kekerasan Terhadap Perempuan dan Anak. PT. PSG dan Pilar Media. hlm. 8-10.

10 Siti Zumrotun. 2006. Membongkar Fiqh Patriarkhis; Refleksi atas Keterbelengguan Perempuan dalam Rumah Tangga. Cet.I,. STAIN Press. hlm. 103.

11 Ibid

12 Elly Nurhayati dan Wahkid Hasyim dalam Riswani. 2005. Penghapusan Tindak Kekerasan terhadap Perempuan ( Suatu Tinjauan terhadap Konseling Berwawasan Gender). Marwah. Vol IV, No 7 Juni, 2005: 1-19

13 Kristi Poerwandari. 2000. Kekerasan Terhadap Perempuan Tinjauan Psikologis dalam buku Penghapusan Diskriminasi Terhadap Wanita. Bandung: Alumni. hlm. 283. Op.cit. Farha Ciciek. hlm. 35-

15 Hamka. 1983. Tafsir al-Azhar. Juz V. Jakarta: Pustaka Panjimas. hlm. 48-49. Husen Muhammad. 2004. Islam Agama Ramah Perempuan Pembelaan Kiai Pesantren. Cet. 1. Yogjakarta: LKIS. hlm. 242.

17 Topo Santoso. 2003. Membumikan Hukum Pidana Islam. Jakarta: Gema Insani. hlm. 73.

18 Op.cit. Siti Zumrotun. hlm. 111.

19 (HR. Tirmidzi)

20 Ibnu Hajar al Asqolani. tt. Bulughul Maram. Semarang: PT. Toha Putra. hlm. 237

21 Milda Marlia. 2007. Marital Rape Kekerasan Seksual Terhadap Isteri. Cet. 1. Yogjakarta: PT. LKiS Pelangi Aksara. hlm. 11

22 Ibid. hlm. 13

23 Masdar F. Mas'udi. 1997. Islam dan Hak-hak Reproduksi Perempuan. Cet. II, Bandung: PT. Mizan Hazanah Ilmu-ilmu Islam. hlm. 113. 
24 Muhammad Thalib. 2000. Ketentuan Nafkah Isteri dan Anak. Cet. I. Bandung: PT. Irsyad Baitus Salam. hlm. 21-22. Ibid. hlm. 117-118.

25 Muhammad bin Umar An-Nawawi. 2000. Syarah Uqudullujain Etika Rumah Tangga. Cet II. Jakarta: Pustaka Amani. hlm. 22.

\section{DAFTAR PUSTAKA}

Hamka. 1983. Tafsir al-Azhar. Juz V. Jakarta: Pustaka Panjimas

Herkutanto. 2000. Kekerasan Terhadap Perempuan dalam Sistem Hukum Pidana. dalam buku Penghapusan Diskriminasi Terhadap Wanita. Bandung: PT. Alumni.

Husen Muhammad. 2004. Islam Agama Ramah Perempuan Pembelaan Kiai Pesantren. Cet. 1. Yogjakarta: LKIS.

Ibnu Hajar al Asqolani. tt. Bulughul Maram. Semarang: PT. Toha Putra.

Kristi Poerwandari. 2000. Kekerasan Terhadap Perempuan Tinjauan Psikologis dalam buku Penghapusan Diskriminasi Terhadap Wanita. Bandung: Alumni.

Marwah. Vol IV, No 7 Juni, 2005

Masdar F. Mas'udi. 1997. Islam dan Hak-hak Reproduksi Perempuan. Cet. II, Bandung: PT. Mizan Hazanah Ilmu-ilmu Islam.

Milda Marlia. 2007. Marital Rape Kekerasan Seksual Terhadap Isteri. Cet. 1. Yogjakarta: PT. LKiS Pelangi Aksara.

Mufidah et al. 2006. Haruskah Perempuan dan Anak Dikorbankan? Panduan Pemula Untuk Pendampingan Korban Kekerasan Terhadap Perempuan dan Anak. PT. PSG dan Pilar Media.

Muhammad bin Umar An-Nawawi. 2000. Syarah Uqudullujain Etika Rumah Tangga. Cet II. Jakarta: Pustaka Amani.

Muhammad Thalib. 2000. Ketentuan Nafkah Isteri dan Anak. Cet. I. Bandung: PT. Irsyad Baitus Salam.

Siti Zumrotun. 2006. Membongkar Fiqh Patriarkhis; Refleksi atas Keterbelengguan Perempuan dalam Rumah Tangga. Cet.I,. STAIN Press.

Topo Santoso. 2003. Membumikan Hukum Pidana Islam. Jakarta: Gema Insani.

UU RI No. 23 tahun 2004 tentang Penghapusan Kekerasan dalam Rumah Tangga. 2006. Cet. II, Desember. Bandung: Pustaka Fokus Media. 
